\title{
Pengembangan Modul Pengelolaan Studi Lanjut Pada Sistem Informasi Sumber Daya Manusia
}

\author{
Husni Thamrin ${ }^{1}$, Hamzah Miftakhuddin ${ }^{2}$ \\ email: Husni.Thamrin@ums.ac.id, hamzahmifta05@gmail.com \\ Universitas Muhammadiyah Surakarta
}

\begin{abstract}
Abstrak
Beasiswa merupakan bantuan keuangan yang ditujukan untuk keberlangsungan pendidikan yang sedang ditempuh. Bagi instansi yang memberikan beasiswa, penting untuk mengelola informasi beasiswa secara efektif untuk menghindari berbagai masalah. Salah satu cara untuk meningkatkan efektifitas pekerjaan adalah dengan memanfaatkan teknologi informasi. Di Universitas Muhammadiyah Surakarta sudah ada sistem informasi sumber daya manusia, namun belum memiliki modul untuk mengelola beasiswa studi lanjut. Penelitian ini bertujuan untuk mengembangkan modul pengelolaan studi lanjut yang berjalan dengan baik dari segi fungsionalitas. Metode pengembangan sistem menggunakan metode prototype dan menggunakan framework Django yang berbasis bahasa pemrograman Python. Hasil dari penelitian ini berupa modul yang digunakan untuk mengelola beasiswa studi lanjut. Berdasarkan pengujian black box, modul dapat berjalan sesuai dengan yang diharapkan dari segi fungsionalitas.
\end{abstract}

Kata kunci : beasiswa, django, python, studi lanjut

\section{Pendahuluan}

Studi lanjut adalah pendidikan lanjutan setelah tamat dari pendidikan yang saat ini ditempuh. ${ }^{[1]}$. Dalam melanjutkan pendidikan yang lebih tinggi, terdapat banyak instansi yang memberikan bantuan keuangan berupa beasiswa kepada perorangan yang ingin melanjutkan studi. ${ }^{[2] .}$ Beasiswa adalah pemberian bantuan kepada perorangan untuk digunakan demi keberlangsungan pendidikan yang ditempuh. ${ }^{[3]}$

Instansi yang memberikan bantuan beasiswa perlu melakukan pengelolaan informasi dengan baik karena data yang disimpan cukup bayak, seperti informasi penerima beasiswa, riwayat pencairan dana beasiswa, perkembangan studi penerima beasiswa, dan laporan dana beasiswa. Banyaknya informasi akan menimbulkan masalah ketika informasi tidak dikelola dengan baik, seperti kehilangan data, kesulitan mencari informasi, redudansi data, kesulitan membuat laporan. Salah satu upaya untuk mengatasi masalah tersebut adalah dengan menggunakan sistem informasi. Sistem informasi dapat mempercepat proses pekerjaan, mengurangi resiko kehilangan data, dan meningkatkan keakuratan data $^{[4]}$ dan dapat memudahkan manajemen dan memastikan efektifitas manajerial. ${ }^{[5]}$

Universitas Muhammadiyah Surakarta (UMS) merupakan perguruan tinggi yang memberi fasilitas beasiswa kepada dosen yang melanjutkan studi di tingkat S3. Perguruan tinggi tersebut telah memiliki sistem informasi sumber daya manusia untuk mengelola data pegawai baik dosen maupun tenaga kependidikan, yang diberi nama SiHRD. Namun sistem informasi tersebut belum memiliki modul untuk mengelola data beasiswa studi lanjut sehingga petugas mengalami kesulitan dalam mengelola data. Petugas membutuhkan waktu yang lama untuk membuat ajuan dana dan membuat laporan ke pimpinan.

Progress studi para penerima beasiswa dilaporkan menggunakan email dan pengarsipannya tidak rapi sehingga menimbulkan kesulitan saat dicari. Oleh karena itu, perlu dikembangkan modul pengelolaan studi lanjut pada sistem informasi sumber daya manusia yang membantu petugas sumber daya manusia dalam mengelola data terkait beasiswa studi lanjut. 


\section{Metode Penelitian}

Metode yang digunakan untuk mengembangkan modul pengelolaan studi lanjut pada sistem informasi sumber daya manusia adalah dengan menggunakan metode SDLC (Software Development Life Cycle) Prototype. Dengan metode Prototype, sistem dibangun, diuji, kemudian dikerjakan kembali sampai prototype dapat diterima oleh klien ${ }^{[6]}$. Alasan menggunakan metode prototype adalah penulis dapat bekerja lebih baik dalam mengembangkan sistem sesuai yang diharapkan oleh klien karena komunikasi yang aktif antara penulis dengan klien. Selain itu, prototype lebih cocok untuk untuk sistem yang dikembangkan untuk memenuhi kebutuhan klien. ${ }^{[7] .}$ Siklus metode prototype bisa dilihat pada gambar 1 .

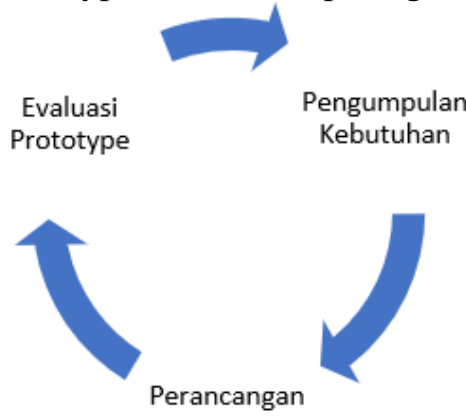

Gambar 1. Siklus metode prototype

Tahapan dari metode SDLC prototype antara lain sebagai berikut:

A. Pengumpulan Kebutuhan

Pada tahap ini, penulis melakukan wawancara dan konsultasi dengan Kepala Biro Teknologi Informasi tentang kebutuhan modul pengelolaan studi lanjut yang akan dikembangkan. Dari wawancara dan konsultasi tersebut diketaui bahwa di sistem informasi sumber daya manusia, belum ada modul yang berfungsi untuk mengelola informasi terkait beasiswa studi lanjut. Maka dari itu, perlu mengembangkan modul untuk mengelola informasi beasiswa studi lanjut.

Dari wawancara tersebut juga didapatkan kebutuhan fungsional antara lain sistem dapat mengelola informasi penerima beasiswa, sistem dapat melakukan pencatatan pencairan dana beasiswa, sistem dapat menghasilkan ajuan dana beasiswa, sistem dapat menampilkan tabel laporan keuangan, dan sistem dapat mengelola perkembangan studi penerima beasiswa. Sedangkan untuk kebutuhan non-fungsional yaitu modul dikembangkan menggunakan framework Django dan menggunakan manajemen basis data $M y S Q L$.

B. Perancangan

Software yang digunakan untuk mengembangkan sistem menggunakan framework Django yang berbasis bahasa pemrograman Python. Alasan memilih Django untuk mengembangkan modul adalah karena sistem informasi yang ada menggunakan framework Django. Python merupakan bahasa pemrograman yang mudah dipahami ${ }^{[8]}$ sedangkan Django merupakan framework berbahasa Python yang open source dan memiliki tools bawaan untuk membangun lingkungan kerja yang tepat dalam membangun sistem ${ }^{[9]}$.

Dalam modul pengelolaan studi lanjut yang akan dikembangkan, modul pengelolaan studi lanjut memiliki 2 jenis user atau pengguna, yaitu petugas HRD dan dosen sebagai penerima beasiswa. Petugas HRD dapat menambah dan mengubah informasi penerima beasiswa, melakukan pencatatan pencairan dana, mengunduh ajuan dana, menampilkan tabel laporan keuangan, dan melihat perkembangan studi penerima beasiswa. Sedangkan penerima beasiswa dapat melihat riwayat pencairan dana beasiswa, mengubah judul thesis atau disertasi, mengubah nama pembimbing thesis atau disertasi, serta mengunggah laporan kemajuan dan laporan akhir studi. Use case diagram dari modul pengelolaan studi lanjut pada sistem informasi sumber daya manusia dapat dilihat pada gambar 2 .

Activity diagram dari penerima beasiswa saat mengelola laporan studi bisa dilihat pada gambar 3 . 


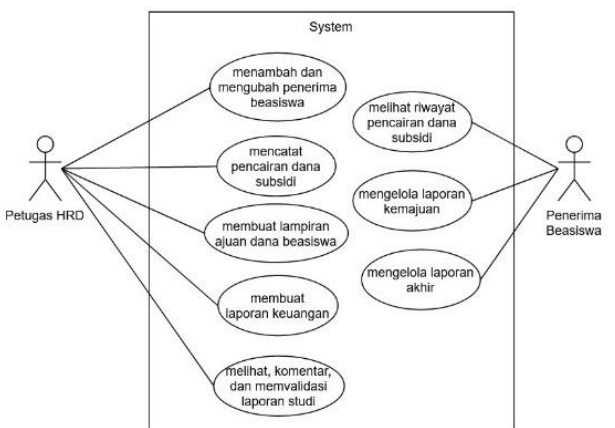

Gambar 2. Use case diagram

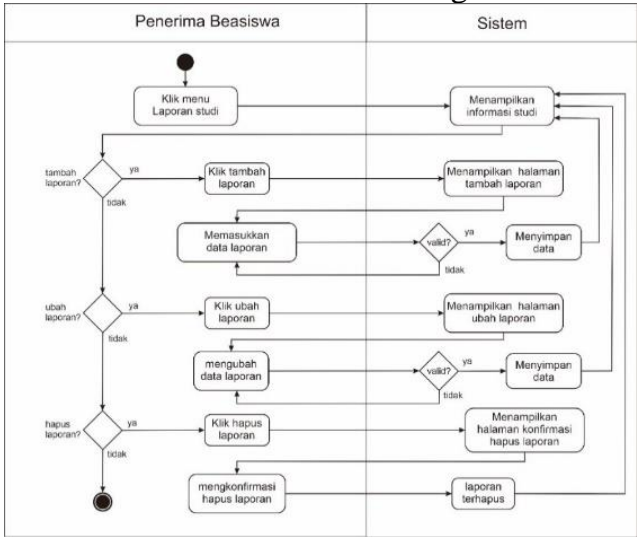

Gambar 3. Activity diagram

Rancangan dari basis data yang akan diimplementasikan pada pengembangan modul pengelolaan studi lanjut pada sistem informasi sumber daya manusia berupa ERD (Entity Relationship Diagram). Model basis data bisa dilihat pada gambar 4. Terdapat entitas negara yang tidak tercantum pada model basis data yang memiliki hubungan one-to-many dengan entitas penerima (atribut negara_pt).

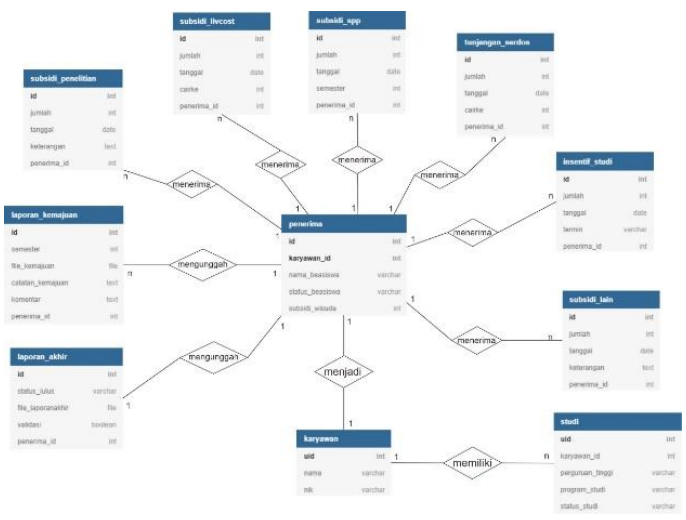

Gambar 4. ERD Modul

User Interface merupakan suatu interaksi antara pengguna dan sistem melalui perintah atau teknik untuk mengoperasikan sistem ${ }^{[10]}$. Desain user interface yang berupa mockup untuk petugas HRD terdapat beberapa menu dan tampilan dari menu yang bisa dilihat pada gambar 5. Sedangkan mockup dari desain user interface untuk jenis pengguna penerima beasiswa dapat dilihat pada gambar 6 .

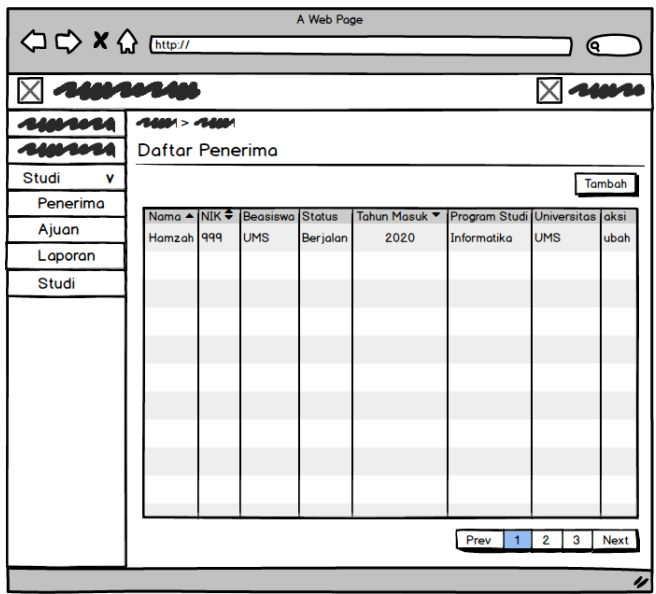

Gambar 5. Mockup user interface petugas HRD

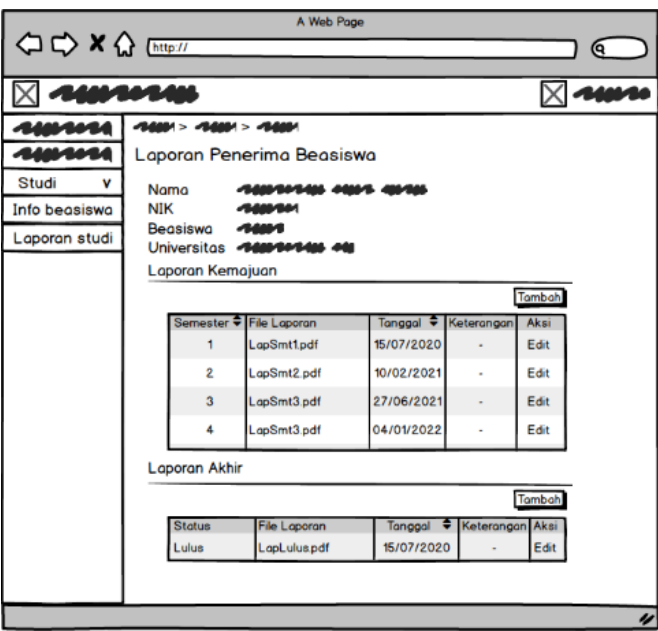

Gambar 6. Mockup user interface penerima beasiswa

C. Evaluasi Prototype

Hasil dari perancangan prototype akan dievaluasi oleh kepala Biro Teknologi Informasi Universitas Muhammadiyah Surakarta. Apabila perancangan yang dibuat sudah sesuai, akan dilanjutkan pada proses implementasi. Namun, apabila perancangan prototype belum disepakati, maka akan mengulangi langkah analisis kebutuhan, perancangan dan evaluasi sampai kebutuhan klien terpenuhi. 


\section{Implementasi}

Pada tahap ini, perancangan prototype yang telah disepakati akan dikembangkan menggunakan framework Django 1.11, dari bahasa pemrograman Python. Sistem manajemen basis data yang digunakan adalah MySQL. Sedangkan untuk tampilan dari modul pengelolaan studi lanjut, rancangan dari user interface akan disesuaikan dengan sistem yang sudah ada.

\section{E. Pengujian Sistem}

Setelah sistem sudah diimplementasikan, sistem akan diuji dengan menggunakan metode black box. Pengujian black box adalah pengujian dengan memeriksa apakah sistem telah berfungsi dengan baik dan sesuai dengan kebutuhan. Pengujian black box digunakan untuk menentukan fungsionalitas aplikasi. ${ }^{[11]}$.

F. Evaluasi Sistem

Pada tahap evaluasi sistem, klien akan mengevaluasi apakah sistem sudah berfungsi sesuai dengan harapan klien. Jika sistem yang telah diuji belum sesuai dengan harapan, maka akan mengulangi proses implementasi dan pengujian sistem sampai memenuhi harapan klien.

\section{G. Menggunakan Sistem}

Sistem yang telah dikembangkan dan telah memenuhi kebutuhan dari klien akan diserahkan kepada Biro TI Universitas Muhammadiyah Surakarta untuk ditambahkan ke dalam sistem informasi sumber daya manusia.

\section{Hasil dan Pembahasan}

Hasil dari penelitian ini berupa sebuah modul pengelolaan studi lanjut di Universitas Muhammadiyah Surakarta. Modul ini kemudian akan diimplementasikan ke sistem informasi sumber daya manusia yang digunakan di Universitas Muhammadiyah Surakarta. Terdapat 2 jenis user atau pengguna, yaitu petugas HRD dan penerima beasiswa. Petugas HRD dapat menambah penerima dan mengubah data penerima, serta melakukan pencatatan, mengubah, dan menghapus pencairan dana subsidi beasiswa. Gambar 7 merupakan tampilan dari halaman menu pengelolaan penerima beasiswa.

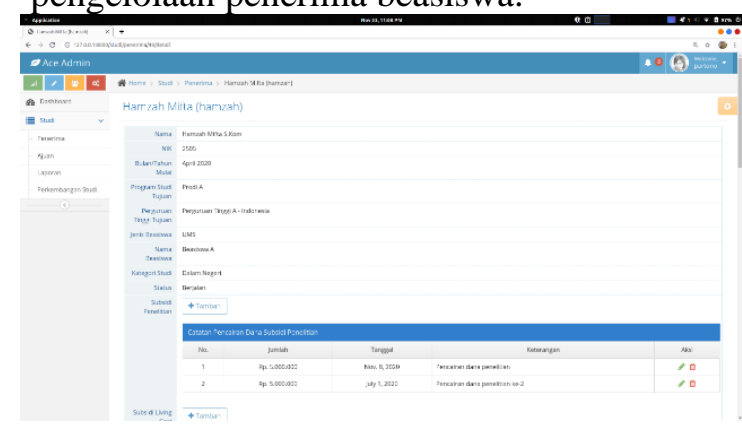

Gambar 7. Tampilan menu penerima beasiswa oleh petugas HRD

Menu ajuan adalah menu untuk membuat lampiran ajuan dana yang berupa dokumen. Petugas HRD perlu memasukkan bulan dan tahun dari ajuan dana yang akan diajukan ke pihak universitas, kemudian sistem akan mengunduh lampiran ajuan dana.

Menu laporan keuangan akan menampilkan tabel yang berisi daftar penerima dan catatan pencairan dana subsidi beasiswa. Petugas HRD memasukkan bulan dan tahun dari laporan yang ingin ditampilkan, kemudian sistem akan menampilkan tabel. Pada menu laporan keuangan juga terdapat fitur untuk export tabel.

Menu perkembangan studi menampilkan informasi tentang perkembangan studi penerima beasiswa. Petugas HRD dapat melihat laporan kemajuan dari penerima beasiswa dan menambahkan komentar jika perlu. Selain laporan kemajuan, laporan akhir dari penerima beasiswa juga bisa dilihat dan divalidasi oleh petugas HRD.

Menu informasi beasiswa menampilkan informasi tentang beasiswa dari penerima. Di menu informasi, penerima dapat melihat riwayat pencairan dana subsidi beasiswa meliputi kategori subsidi, jumlah pencairan, tanggal pencairan, dan lain-lain.

Sedangkan menu laporan studi untuk mengelola laporan kemajuan, laporan akhir, dan untuk mengubah judul thesis atau disertasi serta mengubah nama pembimbing thesis atau disertasi. Tampilan dari menu laporan studi bisa dilihat pada gambar 8 . 


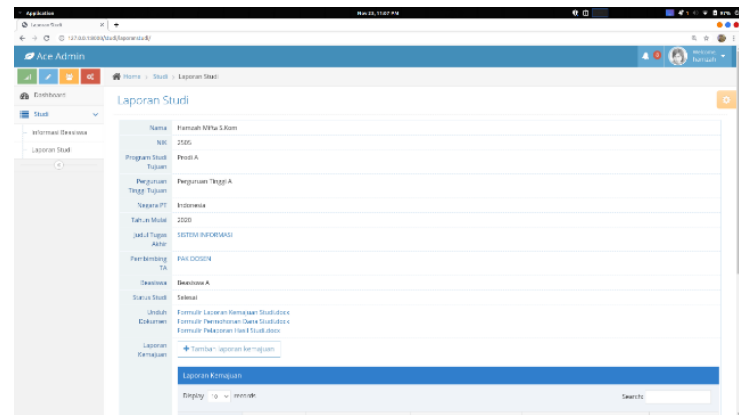

Gambar 8. Tampilan menu laporan studi penerima beasiswa

Pengujian dari modul pengelolaan studi lanjut pada sistem informasi sumber daya manusia dilakukan dengan menggunakan metode pengujian black box. Pengujian black box menguji fungsionalitas sistem apakah berjalan dengan baik dan memenuhi harapan. Berikut adalah hasil dari pengujian menggunakan metode black box modul pengelolaan studi lanjut:

Tabel 1. Hasil pengujian black box

\begin{tabular}{|c|c|c|c|}
\hline No & $\begin{array}{c}\text { Skenario } \\
\text { pengujian }\end{array}$ & $\begin{array}{l}\text { Hasil yang } \\
\text { diharapkan }\end{array}$ & Hasil \\
\hline 1 & $\begin{array}{c}\text { Menambah dan } \\
\text { mengubah } \\
\text { penerima }\end{array}$ & $\begin{array}{c}\text { Berhasil } \\
\text { menambah } \\
\text { penerima dan } \\
\text { menyimpan data } \\
\text { perubahan }\end{array}$ & valid \\
\hline 2 & $\begin{array}{c}\text { Menambah, } \\
\text { mengubah, dan } \\
\text { menghapus } \\
\text { pencairan dana } \\
\text { subsidi }\end{array}$ & $\begin{array}{c}\text { Berhasil } \\
\text { menambah, } \\
\text { mengubah, dan } \\
\text { menghapus } \\
\text { pencairan dana } \\
\text { subsidi }\end{array}$ & valid \\
\hline 3 & $\begin{array}{c}\text { Membuat } \\
\text { lampiran ajuan } \\
\text { dana beasiswa }\end{array}$ & $\begin{array}{c}\text { Mengunduh } \\
\text { dokumen } \\
\text { lampiran }\end{array}$ & valid \\
\hline 4 & $\begin{array}{l}\text { Membuat } \\
\text { laporan } \\
\text { keuangan }\end{array}$ & $\begin{array}{c}\text { Menampilkan } \\
\text { data laporan } \\
\text { keuangan sesuai } \\
\text { bulan dan tahun }\end{array}$ & valid \\
\hline 5 & $\begin{array}{c}\text { Export laporan } \\
\text { keuangan ke } \\
\text { format } c s v\end{array}$ & $\begin{array}{l}\text { Berhasil } \\
\text { melakukan } \\
\text { ekspor ke } \\
\text { format } c s v\end{array}$ & valid \\
\hline 6 & $\begin{array}{l}\text { Memberi } \\
\text { komentar } \\
\text { laporan } \\
\text { kemajuan }\end{array}$ & $\begin{array}{c}\text { Berhasil } \\
\text { menyimpan } \\
\text { komentar pada } \\
\text { laporan } \\
\text { kemajuan }\end{array}$ & valid \\
\hline 7 & $\begin{array}{l}\text { Memvalidasi } \\
\text { laporan akhir }\end{array}$ & $\begin{array}{c}\text { Laporan akhir } \\
\text { tervalidasi }\end{array}$ & valid \\
\hline
\end{tabular}

\begin{tabular}{|c|c|c|c|}
\hline & $\begin{array}{l}\text { penerima } \\
\text { beasiswa }\end{array}$ & & \\
\hline 8 & $\begin{array}{l}\text { Memasukkan } \\
\text { judul thesis } \\
\text { atau disertasi } \\
\text { dan nama } \\
\text { pembimbing }\end{array}$ & $\begin{array}{c}\text { Berhasil } \\
\text { memasukkan } \\
\text { judul thesis atau } \\
\text { disertasi dan } \\
\text { nama } \\
\text { pembimbing }\end{array}$ & valid \\
\hline 9 & $\begin{array}{l}\text { Menambah, } \\
\text { mengubah, dan } \\
\text { menghapus } \\
\text { laporan } \\
\text { kemajuan }\end{array}$ & $\begin{array}{c}\text { Berhasil } \\
\text { menambah, } \\
\text { mengubah, dan } \\
\text { menghapus } \\
\text { laporan } \\
\text { kemajuan }\end{array}$ & valid \\
\hline 10 & $\begin{array}{l}\text { Menambah, } \\
\text { mengubah dan } \\
\text { menghapus } \\
\text { laporan akhir }\end{array}$ & $\begin{array}{c}\text { Berhasil } \\
\text { menambah, } \\
\text { mengubah, dan } \\
\text { menghapus } \\
\text { laporan akhir }\end{array}$ & valid \\
\hline
\end{tabular}

\section{Kesimpulan}

Pengembangan modul pengelolaan studi lanjut pada sistem informasi sumber daya manusia di Universitas Muhammadiyah Surakarta telah selesai dibuat dan dapat berjalan dalam segi fungsionalitas. Modul pengelolaan studi lanjut yang telah dikembangkan dapat melakukan pencatatan pencairan dana subsidi, membuat ajuan dana subsidi, dan membuat laporan keuangan. Berdasarkan hasil pengujian black box, modul dapat berjalan sesuai dengan fungsinya.

\section{Daftar Pustaka}

[1] Ridho RH. Peningkatan Dukungan Keluarga dalam Menentukan Studi Lanjut Siswa. J Educ Econ. 2019;2(2):230-6.

[2] Widianto H, Pratama AP, Laksmi AP. Pengembangan Aplikasi COSYCALSHIP Berbasis Android untuk Pengelolaan Beasiswa Menggunakan Metode Waterfall. J Adv Inf Ind Technol. 2020;2(2):3244.

[3] Helilintar R, Winarno WW, Fatta $\mathrm{H}$ Al. Penerapan Metode SAW dan Fuzzy Dalam Sistem Pendukung Keputusan Penerimaan Beasiswa. Creat Inf Technol J. 2016;3(2):89. 
[4] Bahar JB, Sentinuwo S, Karouw S, Tuturoong N, Robot J, Elektro T, et al. Identifikasi dan Kuantifikasi Manfaat Teknologi Informasi di Kabupaten Talaud. J Tek Inform. 2020;15(1):23-32.

[5] Islam MS, Mamun MA Al. Perception of Management on Outcomes of Human Resource Information System (HRIS). Int J Bus Soc Res. 2016;6(2):29.

[6] Ching TL, Arbaiy NB. Items Searching in Factory Warehouse Using Arduino Module. Int J Adv Sci Comput Eng. 2019;1(1):1-14.

[7] Al chanani U, Thamrin $\mathrm{H}$. Pengembangan Sistem Monitoring Layanan Tata Usaha dan Analisis Kemanfaatannya: Studi Kasus di Fakultas Komunikasi dan Informatika. Proceeding of The URECOL. 2018;(2):114-21.

[8] Thamrin H. Analyzing and
Forecasting Admission data using Time Series Model. J Online Inform [Internet]. 2020;5(1):35-44. Available from: http://join.if.uinsgd.ac.id/index.php/jo in/article/view/546

[9] Sharma V, Kumar R, Sharma R, Mutreja R, Vargis B. Django Framework based ERP for an Institution Data Flow Diagram Level0. Int Res J Eng Technol. 2020;7(5):6099-109.

[10] Joo H. A study on understanding of UI and UX, and understanding of design according to user interface change. Int J Appl Eng Res. 2017;12(20):9931-5.

[11] Verma A, Khatana A, Chaudhary S. A Comparative Study of Black Box Testing and White Box Testing. Int $\mathbf{J}$ Comput Sci Eng. 2017;5(12):301-4. 